J. Clin. Chem. Clin. Biochem.

Vol. 17, 1979, pp. 225-233

\title{
Long-term Observation of Biochemical Effects of Lead in Human Experiments ${ }^{1}$ )
}

\author{
By H. Schlegel and G. Kufner
}

Werksärztlicher Dienst, Daimler-Benz A.G., 7032 Sindelfingen, Federal Republic of Germany

(Received July 20/November 13, 1978)

Summary: In extension of two previous series of experiments, the results of which have been partially reported (1), further long-term tests were performed with daily oral doses of $5 \mathrm{mg} \mathrm{Pb}{ }^{++}$in 2 subjects. Lead in whole blood, free protoporphyrin 9 (III) and 5-aminolevulinate dehydratase activity in erythrocytes, hemoglobin, and urinary 5aminolevulinic acid and coproporphyrin III excretion values were measured.

From experiences with 8 human experiments, three compartmental phases of early detectable lead effect were postulated: 1 . an "ery throcytic" reaction of 5-aminolevulinate dehydratase activity, 2. "hepatic" reactions of 5aminolevulinic acid and coproporphyrin, and 3. an "erythropoietic" reaction of protoporphyrin.

\section{Langzeitbeobachtung biochemischer Bleiwirkungen bei Versuchen am Menschen}

Zusammenfassung: In Fortsetzung zweier vorausgegangener Versuchsreihen, deren Ergebnisse teilweise früher veröffentlicht worden sind (1), wurden weitere Langzeitstudien mit oralen Tagesdosen von $5 \mathrm{mg} \mathrm{Pb}{ }^{++}$bei 2 Versuchspersonen durchgeführt. Sie umfaßten zeitlich dichte Verlaufskontrollen der Werte für Blei im Vollblut, freies Protoporphyrin 9 (III) und 5-Aminolävulinatdehydratase-Aktivität in den Erythrocyten, Hämoglobin und 5-Aminolävulinsäure- sowie Koproporphyrin III-Ausscheidung im Urin.

Schlüsse aus den Erfahrungen an insgesamt 8 Versuchen führten zur Aufstellung der Hypothese, daß bei den früh nachweisbaren Bleiwirkungen drei kompartimentbezogene Phasen zu unterscheiden sind: 1. eine "erythrocytäre" Reaktion der 5-Aminolävulinatdehydratase-Aktivität, 2. eine "hepatische" Reaktion von 5-Aminolävulinsäure und Koproporphyrin, und 3. eine "erythropoetische" Protoporphyrin-Reaktion.

\section{Introduction}

To estimate the usefulness of a toxicological parameter for preventive purposes, including the control of workers exposed to lead, one may start from the following criteria:

1. the specifity, i.e. the degree of exclusiveness in which the chosen parameter responds to the poison under consideration;

2. its sensitivity with regard to

a) the time lag between the start of uptake of the poison and its determinability, or

b) the relation between a given dose of the poison and the magnitude of the response;

1) Data to a communication presented at the International Symposium on Porphyrias and Lead Intoxication, Marburg 1977 (J. Clin. Chem. Clin. Biochem./Vol. 16, 1978/No. 1)
3. the constancy of the response, or the extent to which the measured response is indicative of dosage

a) in every case of application of a certain poisonous substance, and

b) during the whole duration of this influence;

4. the persistence of the response, to be judged from the interval between the end of the admission of the poison and the definite normalization of the respective parameter.

These criteria cannot be determined satisfactorily by means of findings based upon intermittent and/or irregular exposure at the working site. Conditions must permit the periodical intake of known quantities of the poison, and the choice of doses must ensure unequivocal responses of the parameters to be judged. The duration of the experiment, as well as the number and timing of the samples, must be subject to continuous adjustment, depending on the progress of the whole investigation, 
and making allowance for unforeseen events. In short, this is a situation which calls for self-experimentation.

In 1970, we carried out a first study on 2 subjects over a period of 16 weeks, using daily oral doses of $1 \mathrm{mg}$ $\mathrm{Pb}^{++}$. In this preliminary test, apart from a slight increase of protoporphyrin in both subjects (H.S. and H.L.), none of the remaining parameters (hemoglobin, 5-aminolevulinic acid, coproporphyrin, and basophilic punctated ery throcytes = "stippled cells") responded. Therefore, the further choice of doses was made on the basis of our experience over several years with numerous industrial hygiene controls on clinically symptom-free workers. We aimed at values clearly and repeatedly above $153 \mu \mathrm{mol} / 15$-aminolevulinic acid, where we could expect amounts of coproporphyrin above 0.9 $\mu \mathrm{mol} / 1$ and protoporphyrin above $1.78 \mu \mathrm{mol} / 1$. In one third of the cases, there could have been an increase of stippled cells.

After an interval of 5 months, at the end of 1970 we started a second series of experiments, in which a third subject (G.K.) took part (1). Despite elevation of the daily dose to $3 \mathrm{mg} \mathrm{Pb}{ }^{++}$, this subject showed only a slight rise of protoporphyrin near the end of the test, which had been extended to 33 weeks, whereas the remaining parameters did not respond. In the other two subjects (H.S. and H.L.), however, this time there was a marked response of 5-aminolevulinic acid, coproporphyrin, and protoporphyrin, beginning with the third to fourth week of the administration of lead. As to the sequence of their appearence there were no significant differences, but the persistence of the protoporphyrin response considerably exceeded that of the other parameters in both subjects. In none of the cases was there an increase of stippled cells or a decrease of hemoglobin. In a repetition of the same experiment 10 months later, subject H.L., who had shown a very prompt response of 5-aminolevulinic acid and coproporphyrin, failed to respond with these parameters altogether, whereas the protoporphyrin response took place as before.

After completion of our preventive routine program for lead-exposed personnel by the addition of values for 5-aminolevulinate dehydratase and blood lead in 1973, we felt the need for further experiments, in order to get as much information as possible about the relative virtues of the different parameters according to the above outlined postulates. Finally we intended to try a contribution of our own towards the clarification of some of the underlying biochemical processes.

\section{Material and Methods}

\section{Subjects and exposure}

Two male subjects, aged 61 and 36 years, respectively, and occupationally not exposed to lead, received daily oral doses of $5 \mathrm{mg} \mathrm{Pb}{ }^{++}$in the form of an aqueous solution of lead nitrate.
The administration lasted for 6 weeks in one person (H.S.) and 13 weeks in the other (G.K.). With regard to the different body weights the daily exposure was $50 \mu \mathrm{g} / \mathrm{kg}$ or $70 \mu \mathrm{g} / \mathrm{kg}$, which resulted for the total experiment in $2.3 \mathrm{mg} / \mathrm{kg}$ and $6.5 \mathrm{mg} / \mathrm{kg}$ respectively.

Urine and blood samples for determinations of 5-aminolevulinic acid, coproporphyrin, protoporphyrin, blood lead, 5-aminolevulinate dehydratase, and hemoglobin were collected in a somewhat variable manner according to the aforementioned principle. On the chosen days there was a sample of the first urine voiding in the morning, with or without a simultaneous venipuncture done somewhat later in the forenoon.

Laboratory methods

\section{Determination of lead in blood}

$10 \mu \mathrm{l}$ of a hemolyzed blood solution of heparin-stabilized whole blood diluted with dest. water $(1: 6)$ was analyzed via flameless atomic absorption. - Instruments: Perkin-Elmer Model 300 with HGA 72 and $\mathrm{D}_{2} \mathrm{O}$-compensation. Wavelength: $283.3 \mathrm{~nm}$. Molar coefficient of absorbance: $\epsilon=5.4 \times 10^{4} 1$ $\cdot \mathrm{mol}^{-1} \cdot \mathrm{cm}^{-1}$

Accuracy: precision in the series: $\mathrm{CV}=2.6 \%$ precision from day to day: $\mathrm{CV}=6.1 \%$ recovery of added lead: $97.5 \pm 4.5 \%$

Determination of free erythrocyte protoporphyrin, including negligible amounts of coproporphyrin (2)

Accuracy: precision in the series: $\mathrm{CV}=2.7 \%$ precision from day to day: $\mathrm{CV}=5.7 \%$ recovery of added protoporphyrin: $99 \pm 2 \%$

Determination of 5-aminolevulinate dehydratase activity The procedure is in accordance with the standardized method of the European Community (3).

Accuracy: precision in the series: $\mathrm{CV}=3.9 \%$ precision from day to day: indeterminate due to instability of the enzyme.

Determination of hemoglobin

Internationally standardized cyan-methemoglobin method.

\section{Determination of 5-aminolevulinic acid in urine}

The analy tical procedures using thin-layer chromatography on silica gel are described by Kufner \& Schlegel (4).

Accuracy: precision in the series: $\mathrm{CV}=1.1 \%$ precision from day to day: $\mathrm{CV}=2.4 \%$ recovery of added 5-aminolevulinic acid: $99 \pm 1.5 \%$

\section{Determination of coproporphyrin III in urine}

$10 \mathrm{ml}$ urine of a fresh specimen, $6 \mathrm{ml}$ sodium acetate $(4.0 \mathrm{~mol} / 1)$, $9 \mathrm{ml}$ acetic acid conc. (5), and $30 \mathrm{ml}$ diethyl ether are pipetted in to a translucent white closeable plastic bottle (volume $100 \mathrm{ml}$ ), shaken vigorously, and exposed to daylight (6) or to a $60 \mathrm{~W}$ lamp respectively (minimum $3 \mathrm{~h}$ ), to convert coproporphyrinogen to coproporphyrin. After removing the urine-water layer and washing with $10 \mathrm{ml}$ dest. water, coproporphyrin III is analyzed spectrophotometrically in accordance to procedures set forth by Rimington (7).

Accuracy: precision in the series: $\mathrm{CV}=1.9 \%$ precision from day to day: $\mathrm{CV}=4.8 \%$ recovery of added coproporphyrin III: $96 \pm 5 \%$

\section{Statistical evaluation}

Statistical analysis served two purposes: 1 . to observe the course of each parameter, and 2. to demonstrate dependences between blood lead and the other parameters as well as interdependences between the latter.

1. Observation of the course of parameters. - For this, the whole experiment was divided into 3 periods:

a) Preexposure period. - This served to ascertain for each subject the normal range of the respective parameter. This was based upon 5 analyses distributed over a fortnight. An average value with variance was then calculated. 
b) Period of lead uptake. - During the first week daily blood and urine samples were analyzed from Monday through Friday: $n=5$. During the following weeks of lead uptake, samples were analyzed on Mondays, Tuesdays, and Fridays: $\mathrm{n}=3$. For every week an average value and variance were calculated.

c) Postexposure period. - During 11 weeks 3 weekly analyses were maintained, followed by 2 analyses a week, until a definite trend towards normalization of the parameters was obvious; thereafter, analyses were performed once a week. With $\mathrm{n}=2$, only mean values were calculated.

Following the preexposure period, the weekly average with its corresponding variance was compared with the respective preexposure value. Statistical judgement was carried out according to the t-test (Student) for differences of means with heterogenous variance on the basis of small samples, because the F-test had evidenced that the existing data were not homogenous. There was a one-sided test with all parameters. For statistical results see table 1 .

2. Demonstration of dependences between blood lead and the other parameters as well as interdependences between the latter. To judge these criteria, the corresponding single analytical values were consulted in each case. The recognized correlation was calculated as function of regression and by means of the t-test as coefficient of correlation ( $R$. A. Fisher), and the statistical security was characterized in the above-mentioned manner.

\section{Results}

\section{Lead in whole blood}

With subject H.S. (fig. 1), blood lead values rose as early as the 1 st day after the onset of lead administration.

Significantly elevated values existed from the 1 st through the 18 th week; they appeared once more from the 20 th till the 26 th week. A maximum of $\left.3.09(0.19)^{2}\right) \mu \mathrm{mol} / 1$ was reached in the 6 th week. After termination of the lead uptake, normalization of values took place rather quickly during 10 weeks down to $1.58(0.24) \mu \mathrm{mol} / 1$. Definitively the preexposure level was reached after the 31 st week (i.e. 25 weeks after the lead uptake had been terminated.)

2) $\bar{x} \pm s$
With subject G.K. (fig. 6), who extended the uptake of lead to 13 weeks, blood lead values were significantly elevated from the 2 nd week and amounted to 1.45 (0.39) $\mu \mathrm{mol} / 1$ in the 6 th week. By the 17 th week, values around $0.79(0.25) \mu \mathrm{mol} / \mathrm{l}$ fell within the normal range.

\section{Free protoporphyrin 9 (III) in erythrocytes}

With subject H.S. (fig. 2), protoporphyrin values started to rise significantly in the $3 \mathrm{rd}$ week under lead influence. Maximum values averageing $4.44(0.14) \mu \mathrm{mol} / 1$ were attained not before the 19 th week, i.e. 13 weeks after cessation of lead uptake. Normalization, which commenced afterwards, was nearly completed $(0.68$ $\mu \mathrm{mol} / \mathrm{l})$ by the 46 th week. For correlations with blood lead and with other parameters see table 1 .

With subject G.K. (fig. 6), the preexposure level was not significantly exceeded until the 8 th week; the rise of protoporphyrin values was extremely slow. There was a tendency to normalization 6 weeks after the lead uptake had ended. No correlations whatsoever between protoporphyrin and the other parameters could be revealed in this subject.

\section{5-Aminolevulinate dehydratase activity in erythrocytes}

With subject H.S. (fig. 3), significantly lowered values were established from the 1 st till the 39 th week. In this experiment, maximum decrease of 5-aminolevulinate dehydratase down to values about $7.13 \mathrm{U} / 1$, i.e. less than one third of the pre-exposure values, was attained during the 5 th week. At the end of the 1 st week after the lead uptake had been stopped, values started to rise again. In the subject G.K. (fig. 6), as compaired with H.S., 5-aminolevulinate dehydratase values also exhibited a markedly milder response. Decrease of activity started

Tab. 1. Results of statistical evaluations.

\begin{tabular}{|c|c|c|c|c|c|}
\hline Regression of parameters (Subject) & Period & Equation of regression & $\mathbf{t}$ & $\mathbf{r}$ & DF \\
\hline $\begin{array}{l}\text { 1. lead/protoporphyrin (H.S.) } \\
\text { 2. 5-aminolevulinate-dehydratase/ }\end{array}$ & 2.-7. week & $y=2.166+0.277 x$ & 3.858 & $0: 880 * * *$ & 14 \\
\hline $\begin{array}{l}\text { protoporphyrin (H.S.) } \\
\text { 3. lead/5-aminolevulinate-dehy- } \\
\text { dratase (H.S.) }\end{array}$ & $\begin{array}{l}\text { 19. }-46 \text {. week } \\
\text { preexposure time and } \\
1,-3 \text {. week }\end{array}$ & $\begin{array}{l}y=e(0.822-1.804 x) \\
y=2,616-0.060 x\end{array}$ & $\begin{array}{l}3.354 \\
6.911\end{array}$ & $\begin{array}{l}-0.573 * * * \\
-0.990 * * *\end{array}$ & $\begin{array}{l}29 \\
14\end{array}$ \\
\hline $\begin{array}{l}\text { 4. lead/5-aminolevulinate-dehy- } \\
\text { dratase (H.S.) }\end{array}$ & 13. -46 . week & $y=e(0.455-0.686 x)$ & 4.746 & $-0.661 * * *$ & 45 \\
\hline $\begin{array}{l}\text { 5. lead/5-aminolevulinate-dehy- } \\
\text { dratase (G.K.) }\end{array}$ & $\begin{array}{l}\text { preexposure time and } \\
\text { 1. }-8 \text {. week }\end{array}$ & $y=2,243-0,055 x$ & 7.657 & $-0,945 * * *$ & 27 \\
\hline $\begin{array}{l}\text { 6. lead/5-aminolevulinate-dehy- } \\
\text { dratase (G.K.) }\end{array}$ & 9. -12 . week & $y=2,935-0.068 x$ & 7.818 & $-0,984 * * *$ & 10 \\
\hline 7. lead/5-aminolevulinic acid (H.S.) & $\begin{array}{l}\text { preexposure time and } \\
1 .-7 \text {. week }\end{array}$ & $y=-1.522+\ln 0.917 x$ & 4.742 & $0.888 * * *$ & 23 \\
\hline $\begin{array}{l}\text { 8. lead/5-aminolevulinic acid (H.S.) } \\
\text { 9. } 5 \text {-aminolevulinic acid/copro- } \\
\text { porphyrin (H.S.) }\end{array}$ & $\begin{array}{l}\text { 7.-17. week } \\
\text { preexposure time and } \\
\text { 1. }-17 \text {. week }\end{array}$ & $\begin{array}{l}y=-0.112+\ln 0.583 x \\
y=5.591+0.150 x\end{array}$ & $\begin{array}{r}5.984 \\
10.783\end{array}$ & $\begin{array}{l}0.904 * * * \\
0.945 * * *\end{array}$ & $\begin{array}{l}27 \\
52\end{array}$ \\
\hline 10. lead/coproporphyrin (H.S.) & $\begin{array}{l}\text { preexposure time and } \\
1 .-17 \text {. week }\end{array}$ & $y=-2.775+\ln 0.864$ & 4.742 & $0.900 * * *$ & 23 \\
\hline 11. lead/coproporphyrin (H.S.) & 7.-17. week & $y=-2.007+\ln 0.736 x$ & 7.033 & $0.928 * * *$ & 27 \\
\hline
\end{tabular}

Abbreviations: $t=t($ Student $) ; \mathrm{r}=$ coefficient of correlation; $\mathrm{DF}=$ degrees of freedom; $\mathrm{r} * * *=\mathrm{p}<0.001$ 


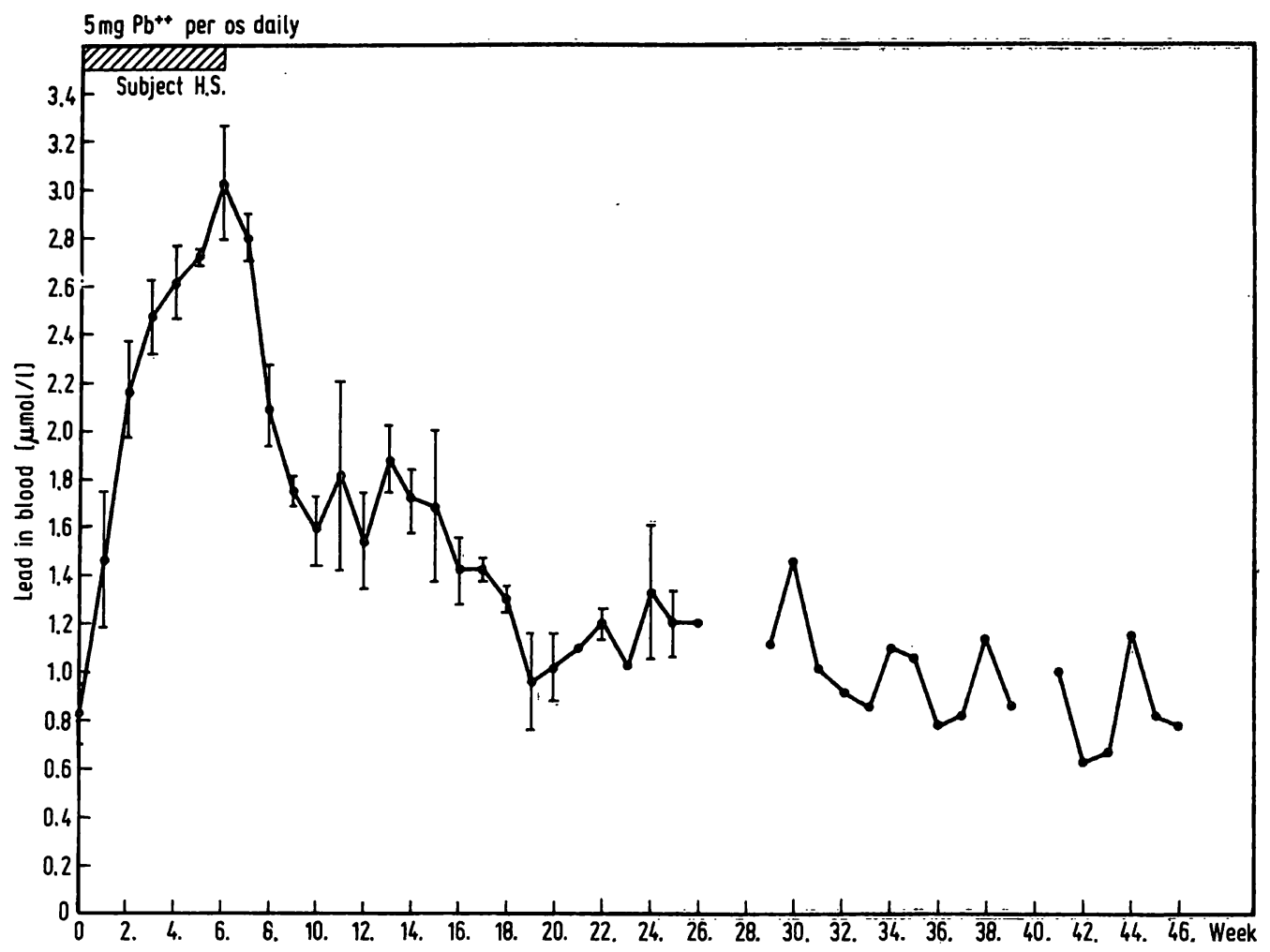

Fig. 1. Course of changes of lead in whole blood in subject H.S., weekly means and standard deviations $(\overline{\mathrm{x}} \pm 1 \mathrm{~s})$.

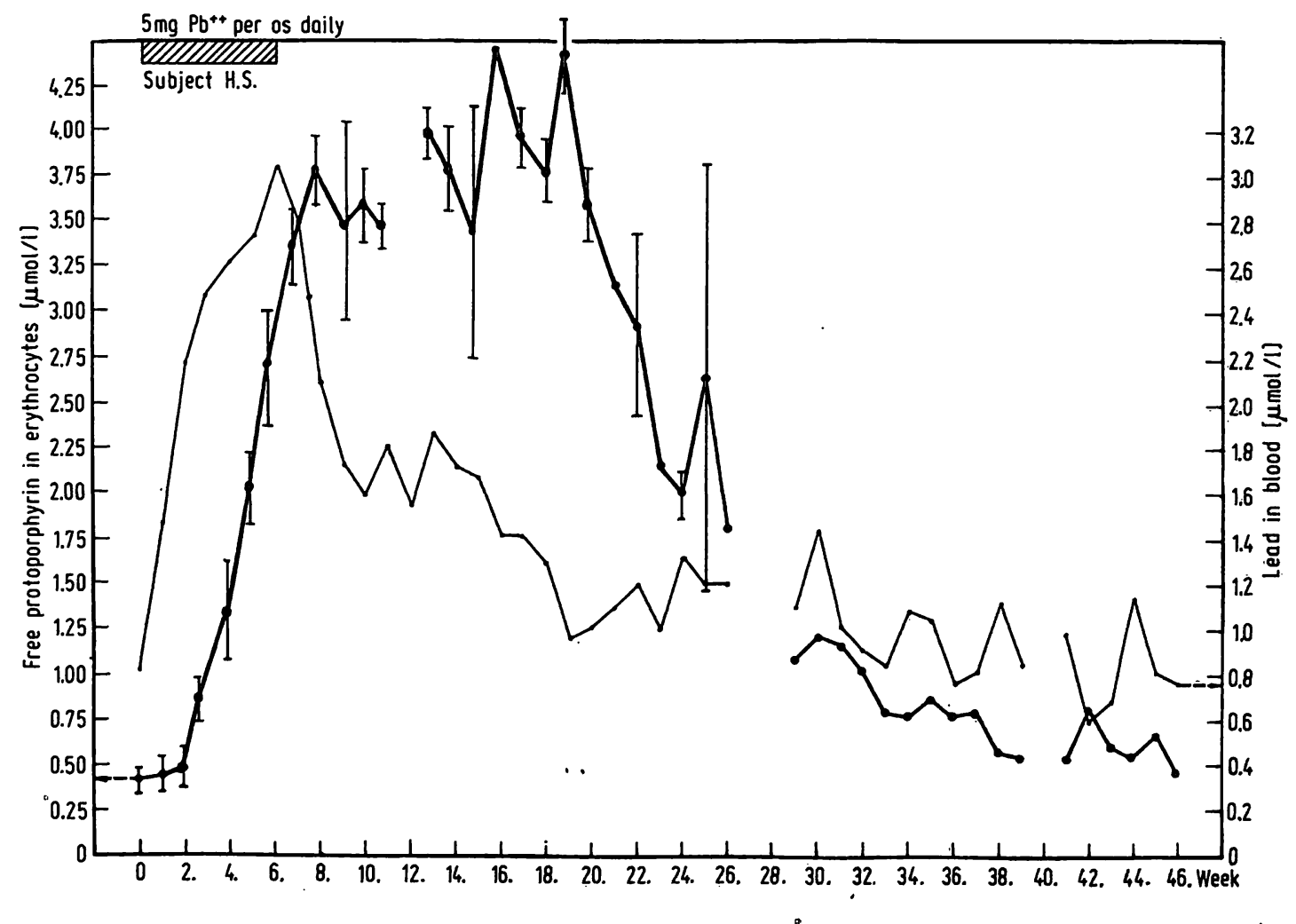

Fig. 2. Course of changes of free protoporphyrin 9 (III) in erythrocytes in subject H.S., weekly means and standard deviations, compared with changes of lead in whole blood. 


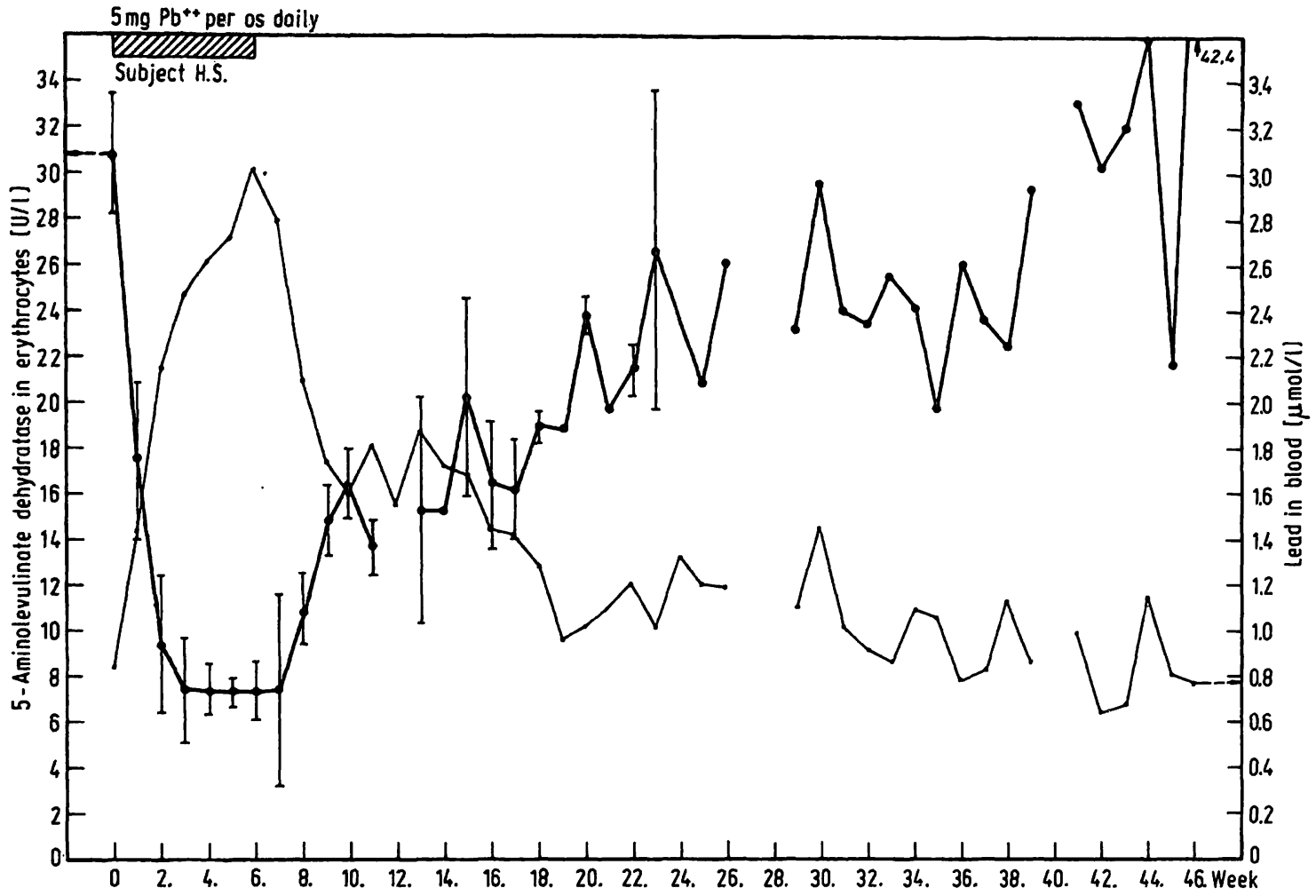

Fig. 3. Course of changes of 5-aminolevulinate dehydratase activity in erythrocytes in subject H.S., weekly means and standard deviations, compared with changes of lead in whole blood.

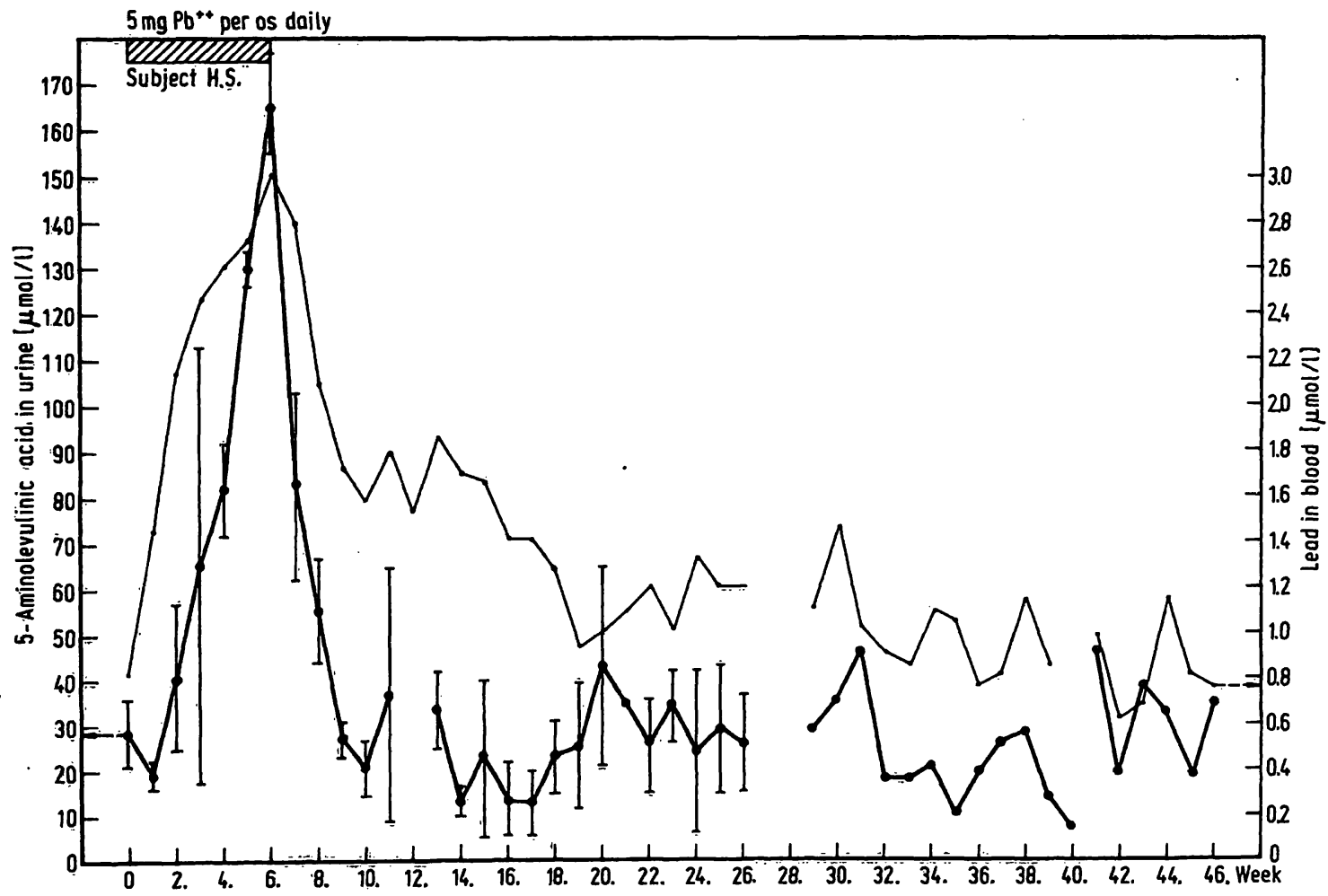

Fig. 4. Course of changes of 5-aminolevulinic acid in urine of subject H.S., weekly means and standard deviations, compared with changes of leād in whole blood. 


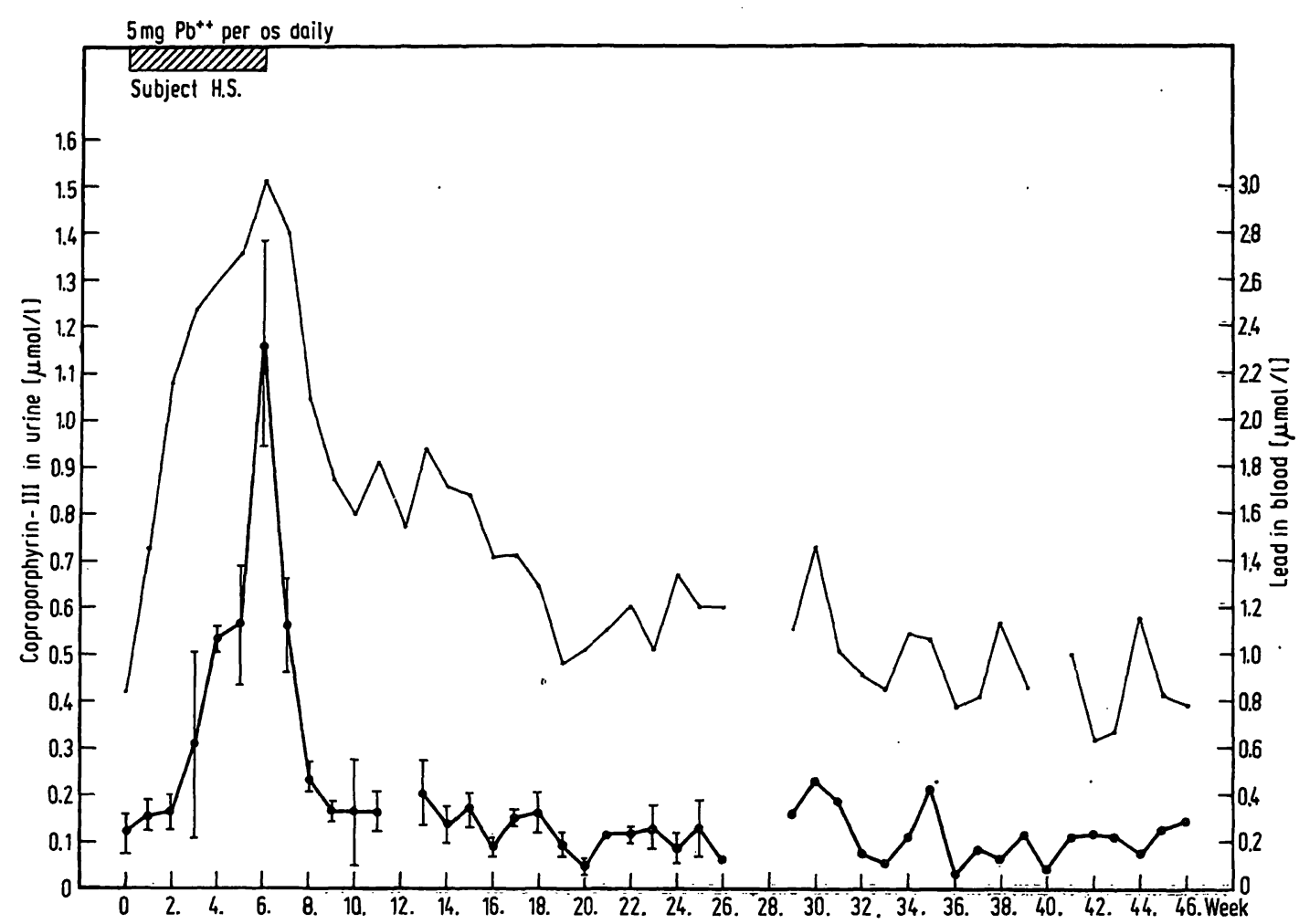

Fig. 5. Course of changes of urinary coproporphyrin-III in subject H.S., weekly means and standard deviations, compared with changes of lead in whole blood.

with the onset of lead uptake and attained a minimum of 14.6 (2.76) $\mathrm{U} / 1$ during the 6 th week. When the lead uptake had been terminated at the end of the 13 th week, normalization took place up to $32.0(2.10) \mathrm{U} / \mathrm{l}$ during the following 10 weeks.

\section{Hemoglobin}

As in our previous tests using smaller doses of lead, there was no noticeable response of hemoglobin values with both subjects in the course of this experiment. Under lead influence, values did not differ significantly from those during the preexposure period. There were no correlations with either blood lead or other parameters.

\section{5-Aminolevulinic acid in urine}

With subject H.S. (fig. 4), 5-aminolevulinic acid started to rise in the $3 \mathrm{rd}$ week and attained a single maximum value of $243.5 \mu \mathrm{mol} / 1$ in the 6 th week. Highly significant elevations lasted from the 4 th through 8 th week. With this parameter, decline to normal values began in the very first week after cessation of lead uptake and was completed in the $3 \mathrm{rd}$ week thereafter.

With subject G.K., 5-aminolevulinic acid values remained unchanged throughout. There were no significant changes relative to the incorporated amounts of lead; no correlations existed with other parameters.

\section{Coproporphyrin-III in urine}

With subject H.S. (fig. 5), coproporphyrin started to rise in the $3 \mathrm{rd}$ week and attained a single maximum value of $1.3 \mu \mathrm{mol} / 1$ in the 6 th week. Values were significantly elevated from the 4 th through the 9 th week. With this parameter, as with 5-aminolevulinic acid, decline to normal values began in the first week after cessation of lead uptake.

With subject G.K., coproporphyrin values also remained unchanged; there were no correlations with blood lead or with other parameters of effect.

\section{Discussion}

As could be expected, our data pertaining to the measuring characteristics of the different parameters of lead uptake and lead effect are essentially in accordance with the findings of Stuik (8) and Cools et al. (9), who exposed volunteers to smaller doses of orally given lead for 3 weeks or 7 weeks, respectively, as well as with those of Tola et al. (10) and Benson et al. (11), who examined workers undergoing occupational lead exposure for the first time in their lives by way of longitudinal surveys of 12 weeks or 4 months, respectively. The authors stated that:

a) there is no time lag in the response of blood lead ( 8 , $9,10,11)$ or of 5 -aminolevulinate dehydratase $(8,9$, 10);

b) responses of heme precursors first appear within 2 to 3 weeks, as do the responses of protoporphyrin (8), 5-aminolevulinic acid $(8,10,11)$, and coproporphyrin $(10,11)^{\circ}$;

c) there is a persistent rise of protoporphyrin values $(8,9)$; 


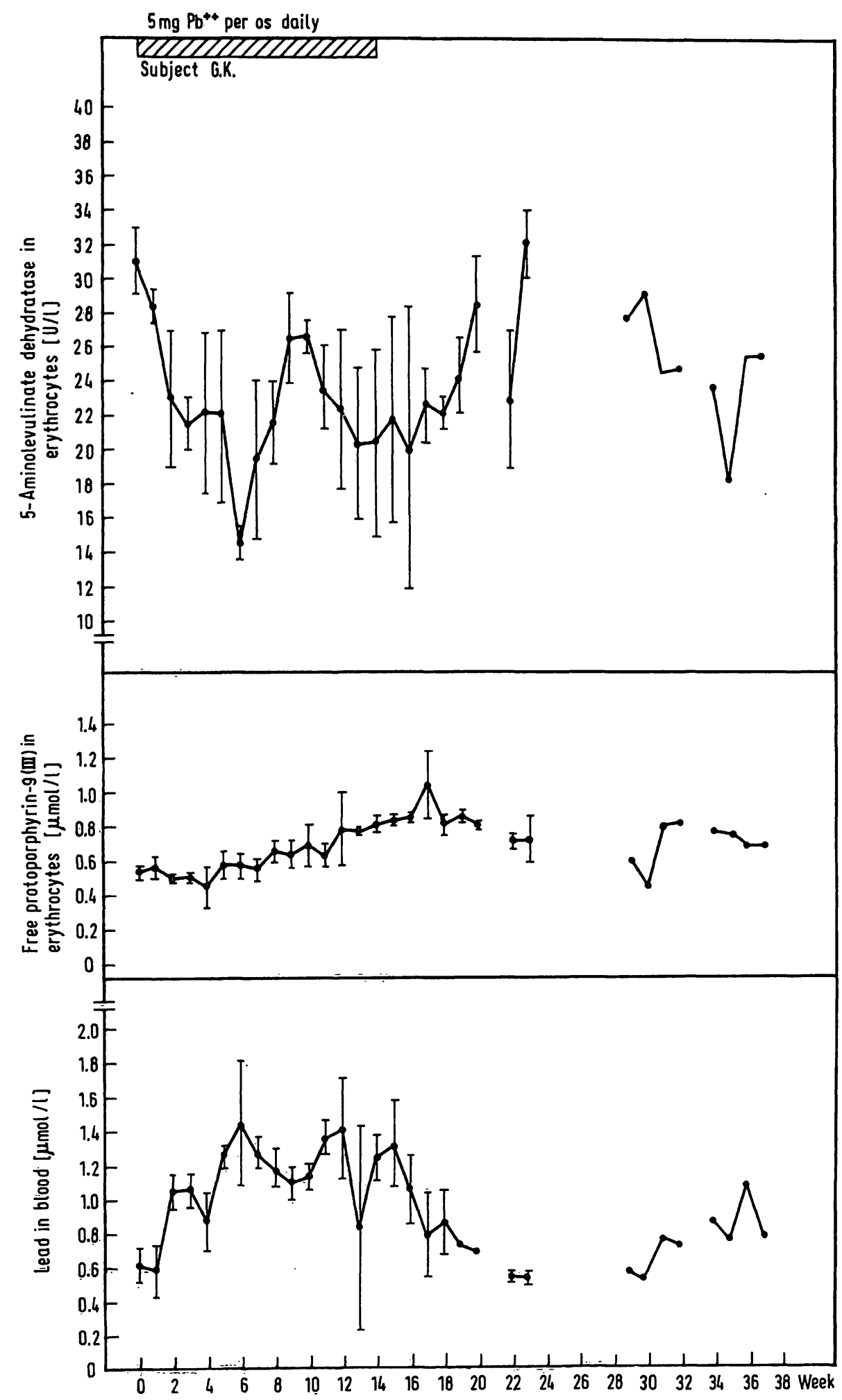

Fig. 6. Course of changes of 5-aminolevulinate dehydratase activity in erythrocytes, free protoporphyrin 9 (III) in erythrocytes, and lead in whole blood in subject G.K., weekly means and standard deviations.

d) changes of 5-aminolevulinic acid and coproporphyrin are more or less well related to each other, showing a similar response pattern of these two parameters (10, 11);

e) sensitivity of hemoglobin seemed to be very low to nil in the experiments of Stuik (8) and Cools et al. (9), whereas Tola et al: (10) recommended observation of the differences in serial estimations to establish small changes as early indicators of lead anemia.

The most outstanding feature of our own series of experiments was the confirmation of an obviously low rate of enteral lead absorption in the subject G.K., as had been observed in our previous experiment (1). We must admit, however, that we cannot offer any clue to 
the explanation of this phenomenon. Dietary causes, particularly high calcium intake, as well as disturbances of gastrointestinal function, can be excluded. Interindividual differences in the susceptibility to lead poisoning have been reported at all times, but to our knowledge were never corroborated in long-term experiments. To elucidate the question as to what mechanism is responsible for this interesting fact remains a toxicological problem which cannot presumably be solved by animal experiments alone.

To what extent can the usefulness of a given laboratory parameter for preventive purposes in current industrial hygiene be judged by the above criteria? On the basis of our experimental results we come to the following conclusions:

\section{Specifity has not been tested, since we did not apply} other poisons besides lead. It may be worth mentioning, however, that during our long-term experiments we never got the impression that alcohol could exercise an influence if taken within the limits of moderate social drinking habits. In cases of high alcohol intake, depression of 5-aminolevulinate dehydratase activity (12) and augmented excretion of coproporphyrin, the latter with respect to its significance as a possible indicator of hepatic disorders (13), might be encountered. From some rather sketchy experiences with heavy drinking individuals, in accordance with Doss \& Schmidt (14), we feel that 5-aminolevulinic acid should also be included in this consideration.

\section{Sensitivity}

a) The time lag between the start of uptake of the poison and the evidence of its presence or effects, is shortest for blood lead and 5-aminolevulinate dehydratase; there seems to be no appreciable time lag at all for these two parameters. Concerning blood lead, this should be a matter of analytical precision alone. For 5-aminolevulinate dehydratase, we assume an immediate and direct effect on the enzyme contained in the circulating ery throcytes, where it no longer serves any purpose in connection with heme synthesis. We therefore designate this first phase of lead effect as the "erythrocytic reaction".

Clearly separated from this are the responses of protoporphyrin, 5-aminolevulinic acid, and coproporphyrin with a time lag of about 3 weeks. Of these, the protoporphyrin response is characterized by its prolonged rise to a peak, which usually comes considerably after the termination of lead uptake. Augmentation of free erythrocyte protoporphyrin is brought about by inhibition of the enzyme ferrochelatase in the erythroblasts, which we call the "ery thropoietic reaction" to lead. The time relations of this phenomenon are subject to the maturation of red cells.
Increased excretion of 5-aminolevulinic acid and coproporphyrin appears synchronously. Of these heme precursors, the amounts lost via the urine in some clinically symptom-free, non-anemic individuals may be so high that the bulk of their origin must be localized in the liver. Therefore, we propose to call this the "hepatic reaction" to lead uptake.

b) With regard to the relation between the dose of the poison and the magnitude of the response, sensitivity is highest with 5 -aminolevulinate dehydratase and protoporphyrin, whereas the "hepatic" parameters will not respond to low lead uptake, hence their usefulness for deliminating decisions in preventive industrial hygiene.

\section{Constancy of response:}

a) the reproducibility of the effect must be questioned at least for 5-aminolevulinic acid and coproporphyrin, which failed to respond a second time with subject H.L. in our previous experiment (1);

b) for the whole duration of lead influence there was a remarkable lack of constancy concerning 5-aminolevulinate dehydratase with subject G.K. in this series of experiments. With 5 -aminolevulinic acid and coproporphyrin, there may be adaptation mechanisms with prolonged uptake of moderate amounts of lead.

4. Persistence of the response seems to be highest with protoporphyrin, due to its medullary origin. In lead anemia, a similar time lag should be expected for hemoglobin as well. Persistence of 5-aminolevulinate dehydratase inhibition was at least as high as the continuance of elevated blood lead values in the scope of our experiments. Moreover, we got the impression that augmented protoporphyrin could possibly exercise a feedback influence on 5-aminolevulinate dehydratase activity. Though statistically we could secure correlations between protoporphyrin and 5aminolevulinate dehydratase on the one hand (table 1, No. 2), and between blood lead and 5-aminolevulinate dehydratase on the other (table 1, No. 3), we are not able to judge them for their pathognomonic conclusiveness, since both of them are known $(15,16)$ as inhibitors (protoporphyrin competitive, blood lead non-competitive) of 5-aminolevulinate dehydratase.

The most limited persistence exists in the "hepatic reaction" of 5-aminolevulinic acid and coproporphyrin, where the decline of values after termination of lead uptake regularly showed a clearly steeper slope than the gradient of increase under lead influence. We attribute this to a sudden adjustment of lead level in the portal venous blood to that of the systemic circulation, when lead absorption via the enteral pathway is interrupted. 
With respect to the relative virtues of the different parameters concerning the early diagnosis of lead poisoning, one cannot easily put up a sequence of their validity, so as to single out the most suitable and discard the rest of them.

At a screening stage, 5-aminolevulinate dehydratase activity in blood and urinary excretions of 5-aminolevulinic acid and coproporphyrin will answer the question, as to whether a lead effect may exist at all and what its magnitude might be. Because of their limited lead specifity, repeatedly abnormal results of the aforementioned parameters must be supported by measurements of blood lead and protoporphyrin.

For preventive purposes, the hemoglobin value as well as stippled cell count must be regarded as obsolete because of their low sensitivity or manifestation rate, respectively.

\section{References}

1. Schlegel, H., Kufner, G. \& Leinberger, H. (1973), Environmental Health Aspects of Lead, Int. Sympos. Amsterdam 1972, CEC Centre for Information \& Documentation, Luxembourg, pp. 569-580.

2. Schlegel, H., Kufner, G. \& Leinberger, H. (1972), Blei und Umwelt, ed. by Verein f. Wasser-, Boden- u. Luf thygiene, Berlin, pp. 67-69.

3. Berlin, A. \& Schaller, K. H. (1974), J. Clin. Chem. Clin. Biochem. 12, 389-390.

4. Kufner, G. \& Schlegel, H. (1973), J. Chromatog. 85, 109122.

5. Gajdos-Török, M. (1968), personal communication

6. Mappes, R. (1971), Int. Arch. Arbeitsmed. 28, 26-36.

7. Rimington, C. (1960), Biochem. J. 75, 620-623.

8. Stuik, E. J. (1974), Int. Arch. Arbeitsmed. 33, 83-97.
9. Cools, A., Sallé, H. J. A., Verberk, M. M. \& Zielhuis, R. L. (1976), Int. Arch. Occup. Environ. Hith. 38, 129-139.

10. Tola, S., Hernberg, S., Asp, S. \& Nikkanen, J. (1973), Brit. J. Industr. Med. 30, 134-141.

11. Benson, G. I., George, W. H. S., Litchfield, M. H. \& Seaborn, D. J. (1976), Brit. J. Industr. Med. 33, 29-35.

12. Krasner, N., Moore, M. R., Thompson, G. G., McIntosh, W. \& Goldberg, A. (1974), Clin. Sci. 46, 415-418.

13. Watson, C-J., Sutherland, D. \& Hawkinson, V. (1951), J. Lab. Clin. Med. 37, 8.

14. Doss, M. \& Schmidt, A. (1971), J. Clin. Chem. Clin. Biochem. 9, 99-102.

15. Heilmeyer, L. (1964), Die Störungen der Bluthämsynthese, Thieme Stuttgart, p. 72.

16. Doss, M. (1974), personal communication.

Dr. H. Schlegel

G. Kufner

Werksärztlicher Dienst

Daimler-Benz A.G.

D-7032 Sindelfingen 
